UDC 330.101

JEL Classification: 121, 122, 011

http://doi.org/10.21272/mmi.2019.3-10

Serhiy Shkarlet,

D.Sc., Professor, Rector, Chernihiv National University of Technology, Ukraine

Nataliia Kholiavko,

Ph.D., Associate Professor, Chernihiv National University of Technology, Ukraine

Maksym Dubyna,

D.Sc., Associate Professor, Chernihiv National University of Technology, Ukraine

\title{
INFORMATION ECONOMY: MANAGEMENT OF EDUCATIONAL, INNOVATION, AND RESEARCH DETERMINANTS
}

\begin{abstract}
A global trend of economic development is the transition to the formation of a new economic paradigm - the information economy. Ability to generate knowledge and innovation is a prerequisite for improving the competitiveness of the country and its regions; as well, it determines the pace of their social and economic development. In this context, the need to determine the levels of the development of the information economy and its structural components (educational, research and innovation) in the regions of the country is actualized. The purpose of the article is to develop and test a methodological toolkit for assessing the development of the information economy in terms of its structural components, that will allow for the formation of regional clusters by the intensity of educational, innovation and research components, and to identify priority vectors for stimulating the development of the information economy at the macro- and meso-economic levels. When developing methodological tools, the authors proceeded from existing methodological approaches in the world, the possibility of adapting them to national specifics, as well as the potential of statistical bases. In order to cluster the regions of Ukraine by the development level of educational, innovation and research components of the information economy, the k-means algorithm is used. The conducted cluster analysis showed that processes of the formation of the information economy in Ukraine are developing unevenly and are in the stage of formation. More regions of the state fall into the cluster of problematic regions with low levels of the development of educational, innovation and research components; leadership in the development level of the information economy is demonstrated by Kharkiv region, assigned to the cluster of regions with the intensive development of the information economy; in addition, a cluster of perspective regions with the level of the moderate development of the information economy is highlighted. The research made it possible to find out the main problems and identify areas of regional imbalances in the development of the information economy, including in terms of its structural components. In conclusions, the authors proposed directions to improve the approaches to the government control of the processes of the information economy evolvement, based on specific features of the regions, their smart specialization, actual capacities and the achieved level of the development of the information economy components.
\end{abstract}

Keywords: information economy, region, innovations, higher education, $R \& D$, cluster, educational, innovation, research components.

Introduction. The global trend of economic development is a transition to the formation of a new economic paradigm - the information economy. A new type of economic system is characterized by the intensification of knowledge-intensive types of production. In such circumstances, education, science and innovation turn into productive forces of the society. The ability to generate knowledge and innovation becomes a prerequisite for improving the competitiveness of the country and its regions, as well, determines paces of their social and economic development. The degree of the country's integration into the global area depends directly on the level of the development of higher education, R\&D and innovation.

The most representative index of the information society development in the countries of the world is the Information and Communications Technology Development Index (IDI), which is computed annually by the UN ITU (International Telecommunication Union). Iceland, the Republic of Korea, Switzerland,

Cite as: Shkarlet, S., Kholiavko, N., Dubyna, M. (2019). Information Economy: Management of Educational, Innovation, and Research Determinants. Marketing and Management of Innovations, 3, 126-141. http://doi.org/10.21272/mmi.2019.3-10 
S. Shkarlet, N. Kholiavko, M. Dubyna. Information Economy: Management of Educational, Innovation, and Research Determinants

Denmark, and the United Kingdom are the IDI rating leaders. Moreover, the retrospective analysis shows that first positions of this rating are the countries characterized by positive dynamics and high investment volumes of innovatively active enterprises, universities and research institutes (Table 1). In 2017, Ukraine ranked only the 79th among 176 countries in the world. Whereas in 2002 Ukraine was ranked the 59th, in 2012 - the 71th. Thus, Ukraine occupies a mediocre position in the global space in terms of the pace of the information society development.

Table 1. Ranking of the countries by IDI

\begin{tabular}{|c|c|c|}
\hline Region & Top-5 & Ukraine's rank \\
\hline World & 1 - Iceland; 2 - Korea (Rep.); 3 - Switzerland; 4 - Denmark; 5 - United Kingdom & $\begin{array}{c}79 \text { (out of } 176 \\
\text { countries) }\end{array}$ \\
\hline $\mathrm{CIS}$ & 1 - Belarus; 2 - Russian Federation; 3 - Kazakhstan; 4 - Moldova; 5 - Azerbaijan & $\begin{array}{c}8 \text { (out of } 10 \\
\text { countries) }\end{array}$ \\
\hline Developed Countries & 1 - Iceland; 2 - Switzerland; 3 - Denmark; 4 - United Kingdom; 5 - Netherlands & $\begin{array}{c}44 \text { (out of } 46 \\
\text { countries) }\end{array}$ \\
\hline Eastern Partnership & 1 - Belarus; 2 - Moldova; 3 - Azerbaijan; 4 - Georgia; 5 - Armenia & $\begin{array}{l}6 \text { (out of } 6 \\
\text { countries) }\end{array}$ \\
\hline
\end{tabular}

Sources: compiled by the authors on the basis of (ICT Development Index, 2017)

In our opinion, the national economy is a complex social and economic system, which structural components are the economies of the country's regions. Accordingly, the pace of the formation and development of the information economy in the country correlates with the pace of regional development. Significant disparities in the development of educational, innovation, research components, and negative manifestations of decentralization processes, changes in correlation between the center and regions, as well as significant differences in the levels of the social and economic development of Ukrainian regions negatively affect the prospects of the economy informatization. This substantiates the need to improve the public policy for stimulation the development of higher education, science and innovation, not only at the national but also at the regional level. Consequently, the need to determine levels of the development of the information economy and its structural components (educational, research, innovation) in the regions of the country is actualized. To this end, we will conduct a cluster analysis because it enables the compression of data, that is, the aggregation of a large body of data into several groups. Grouping within the same cluster of several maximally similar objects makes it possible to study not each object individually, but to study their groups. This optimizes time and the research process as a whole; there is an opportunity to conduct the in-depth analysis, identify trends, specify problems and outline prospects of intensifying the information economy development in the country by targeting the intensification of its educational, research and innovation components at the meso-economic level.

Literature Review. Fundamental principles for the study of transformations of the modern society in the period of its informatization are laid in the works of Bell D. (1973), Toffler A. (1980) and Masuda Y. (1983).Peculiarities of the information economy evolvement within the information society are studied by Castells M. (1997) and Porat Mark U. (1977). At the same time, there is a number of research questions, which require further elaboration. They include the need to analyze the development of the information economy, identify current trends and outline issues and areas of regional imbalances. Clustering is one of the methods of this analysis. Clustering belongs to the class of machine learning tasks and involves self-directed learning («unsupervised learning»-«learning without a teacher»). Due to this, we get an effective tool for the automatic division of objects into classes; such a distribution is based on the criterion of similarity of the analyzed objects.

Key questions of the cluster analysis are revealed in works of Ky'm Dzh.-O. (1989) and Jain A., Murty M., Flynn P. (1999). Clustering is quite actively used in modern economic research, i.e. when 
studying clusters in the institutional economy (Vojnarenko M., 2011); by analyzing clusters within the global economy (Sokolenko S., 2004); when identifying prospects for the development of Euro regions (Mikula N., 2003); in determining the features of the impact of regional clusters on the recovery of the economic development (Bezvushko Ye., 1999), etc.

A. Butenko and Ye. Lazaryeva (2009) research the role of clusters by the development of the innovation model of the region's economy. Within the article by Vojtovy ch A. (2010), results of the clustering of the regions of Ukraine by the level of the social and economic development (by using dynamic and spatial methods of the cluster analysis) are presented. Ivanov Yu., Tyshchenko V. (2015) have conducted the clustering of regions by the level of the development of the knowledge-based economy, in particular, in terms of its structural components. Korepanov 0. (2018) attempted to assess the territorial development of the information society in Ukraine. This was done by adapting the UN methodology to determine the ICT development index (in terms of sub-access index, sub-use index and sub-skill index).

At the same time, modern approaches to the grouping of regions by the level of the information economy development have not been adequately reflected in the scientific literature, including their clustering by educational, innovation and research components of the national economy informatization. In order to fulfill this task, we used the k-means algorithm (Hartigan \& Wong, 1979) from the set of methods of the cluster analysis. The k-means algorithm refers to non-hierarchical methods of the cluster analysis, it is an iterative method of dividing a set of data $m$ into a given number of clusters $k$ ( $k \leq$ $\mathrm{m})$.Under this method, clusters are researched (learned) independently, without further specifying their number or requesting information about the affiliation of objects to specific clusters.

The k-means algorithm assumes the formation of new clusters that are as far apart as possible. The separation of clusters continues until the so-called stopping rule is executed, i.e. reaching a state where the composition of the cluster does not differ from that achieved one in the previous iteration of the distribution. The approach of the k-means algorithm is to minimize the difference between the objects selected for clustering. This algorithm is based on the hypothesis that there is a probable number of clusters $\mathrm{k}$; an appropriate assumption is made based on the results of the previous research, the researcher's intuition, or theoretical reasoning.

When choosing a clustering method, we focused on the algorithm given the strengths inherent in it, i.e. testability, speed and ease of use (by calculating automation); clarity and transparency of both the algorithm itself and the results obtained. In addition, the k-means algorithm is not without its disadvantages: the increased sensitivity to factors capable of influencing average values of the cluster; the likelihood of complexity when processing large databases; a focus on working with continuous (rather than discrete) data.

Within the number of modern scientific works, the action of k-means algorithm is described (Pankaj, 2004; Artuhur \& Vassilvitskii, 2007; Har-Peled \& Sadri, 2005). Think tank (Kanungo et. al, 2004) in copublishing offers the authors' approach to the formation of the simplified k-means algorithm applied practically. However, this approach has a major drawback - slowness, which is a considerable time losses for its use.

Within his research, D. Arthur and S. Vassilvitskii (2006-2007) focus on the quantitative assessment of the duration of the k-means algorithm. The work of L.Bottou and Y. Bengio (1995) is partially devoted to the issues of the use rate. In their co-publishing, they prove, that the use of Newton's fast algorithm in the clustering by the k-means algorithm allows minimizing the quantization error.

D. Sculley (2010) proposes two modifications of the k-means algorithm to optimize it and reduce its cost. The article focuses on the difficulties that the users of web application face.

As well, the article of C. Elkan (2003) is devoted to the acceleration of the k-means algorithm. In addition, it is emphasized that acceleration should not lead to a decrease in the level of accuracy of the 
S. Shkarlet, N. Kholiavko, M. Dubyna. Information Economy: Management of Educational, Innovation, and Research Determinants

obtained clustering results. The acceleration algorithm proposed in the article of $\mathrm{C}$. Elkan is tested on the big batch of objects (up to 1000 measurements). However, the author himself in the article cites some limitations of the developed algorithm. Therefore, issues of accelerating the process of the use of the k-mean algorithm remain open (Wu \& Kumar, 2009; Mielikainen, 2002). However, given all its shortcomings and positives, we believe that this algorithm is an effective research tool and can be used to cluster regions of Ukraine by the development level of educational, research and innovation components of the information economy.

Methodology and research methods. In order to cluster the regions of Ukraine by the level of educational, innovation and research components of the information economy, a two-stage analysis was conducted by us:

1) on the first stage, the model is learning - clusters recognition was taking place;

2) on the second stage, the model is testing - identification of its accuracy and direct clustering by the k-means algorithm with the formulation of conclusions and recommendations that are adequate to the results obtained.

In the course of the study, official statistics of the website of the State Statistics Service of Ukraine were used. When selecting partial metrics for the clustering, we focused on the publicly available opensource database. However, some difficulties have arisen, as today there are no statistics on some required indicators (Table 2). In addition, it is important to note that results of the clustering were significantly influenced by the absence of official statistical databases in Luhansk, Donetsk regions and the Autonomous Republic of Crimea (because of the inability to monitor them due to the temporary occupation of these territories). We also deliberately excluded statistical data of Kyiv from the initial information base, which is justified by a special administrative status of the capital, advantages of the development in comparison with other regions. The need is due to the fact that otherwise clustering would not show a real picture of the potential and actual state of the information economy development in the regions.

Table 2. Input data to cluster regions by the development level of innovation, educational, research components of the information economy

\begin{tabular}{|l|l|c|}
\hline Component & \multicolumn{1}{|c|}{ Partial indicators } & Symbols \\
\hline \multirow{5}{*}{$\begin{array}{c}\text { Educational } \\
\text { (IRedu) }\end{array}$} & number of higher education institutions of the III-IV levels of accreditation & $\mathrm{Er}_{1}$ \\
\cline { 2 - 3 } & $\begin{array}{l}\text { number of students of higher education institutions of the III-IV levels of } \\
\text { accreditation }\end{array}$ & $\mathrm{Er}_{2}$ \\
\cline { 2 - 3 } & number of postgraduates & $\mathrm{Er}_{3}$ \\
\cline { 2 - 3 } & number of Ph.D. candidates & $\mathrm{Er}_{4}$ \\
\cline { 2 - 3 } & number of employees involved in R\&D who have received higher education & $\mathrm{Er}_{5}$ \\
\cline { 2 - 3 } & number of higher education institutions which train Ph.D.candidates & $\mathrm{Er}_{6}$ \\
\cline { 2 - 3 } & number of higher education institutions which train postgraduates & $\mathrm{Er}_{7}$ \\
\cline { 2 - 3 } & number of students of higher education institutions pro 10000 of population & $\mathrm{Er}_{8}$ \\
\hline \multirow{5}{*}{$\begin{array}{l}\text { Innovation } \\
\text { (IRinn) }\end{array}$} & share of innovation-driven industrial enterprises & $\mathrm{Ir}_{1}$ \\
\cline { 2 - 3 } & number of introduced new technological processes & $\mathrm{I}_{2}$ \\
\cline { 2 - 3 } & the volume of introduced innovative types of products & $\mathrm{Ir}_{3}$ \\
\cline { 2 - 3 } & amount of costs for innovative activity of industrial enterprises & $\mathrm{Ir}_{4}$ \\
\cline { 2 - 3 } & share of sold innovative products in the volume of industrial one & $\mathrm{Ir}_{5}$ \\
\cline { 2 - 3 } & patents for inventions for regions (national applicants) & $\mathrm{Ir}_{6}$ \\
\cline { 2 - 3 } & share of enterprises involved in innovation & $\mathrm{Ir}_{7}$ \\
\cline { 2 - 3 } & number of applications for inventions from national applicants & $\mathrm{Ir}_{8}$ \\
\hline
\end{tabular}


S. Shkarlet, N. Kholiavko, M. Dubyna. Information Economy: Management of Educational, Innovation, and Research Determinants

Continued Table 2

\begin{tabular}{|c|l|c|}
\hline \multirow{4}{*}{$\begin{array}{c}\text { Research } \\
\text { (IRsc) }\end{array}$} & number of organizations performing R\&D & $\mathrm{Sr}_{1}$ \\
\cline { 2 - 3 } & number of scientists & $\mathrm{Sr}_{2}$ \\
\cline { 2 - 3 } & amount of costs for R\&D & $\mathrm{Sr}_{3}$ \\
\cline { 2 - 3 } & amount of internal running cost for fundaments research & $\mathrm{Sr}_{4}$ \\
\cline { 2 - 3 } & amount of internal running costs for performing research & $\mathrm{Sr}_{5}$ \\
\cline { 2 - 3 } & $\begin{array}{l}\text { amount of internal running costs for performing scientific and technical } \\
\text { developments }\end{array}$ & $\mathrm{Sr}_{6}$ \\
\cline { 2 - 3 } & number of Doctors of Sciences, employees involved in R\&D & $\mathrm{Sr}_{7}$ \\
\cline { 2 - 3 } & number of Candidates of Sciences/Doctors of Philosophy involved in R\&D & $\mathrm{Sr}_{8}$ \\
\hline
\end{tabular}

Sources: compiled by the authors

The methodology of the conducted research is organized as follows. Section 1 is devoted to the reveal of the clustering algorithm used in the article. Within Section 2, results of the algorithm approbation are presented, in particular: clustering of the regions of Ukraine by the development level of the information economy, the structure of this Section is according to three isolated components, i.e. innovation, educational and research. Section 3 contains the author's interpretation of the obtained results of calculations. In final Section 3, prospects of the development intensification of the information economy both on the macro-economic (national economy) and meso-economic (regions and clusters of the regions) levels are presented.

The purpose of the article is to conduct a thorough analysis of the development of innovation, educational and research components of the information economy in the regions of Ukraine by means of the methodology of the cluster analysis.

Results. K-means clustering algorithm. Nowadays, the algorithm proposed in 1979 by Hartigan J.A. and Wong M.A is widely used, since it is characterized by the efficiency, relative simplicity and sufficient virtue of the results obtained. The basic idea of the algorithm is to divide the set of observations into clusters in such a way that: the average of the cluster objects are as different from each other as possible; distances (differences) between objects of one class are minimal; distances between objects of different classes are maximal; the total quadratic deviation of the cluster points from the centroids (i.e. the coordinate mean of the clusters) is minimal (1):

$$
\min \left[\sum_{i=1}^{k} \sum_{x}(j)_{\epsilon} S_{i}\left\|x^{(j)}-\mu_{i}\right\|^{2}\right]
$$

where, $\mathrm{x}$ - input values, $x^{(j)} \in R^{n}, \mu_{i} \in R^{n}$

$\mu_{i}-$ centers of clusters $\mathrm{S}_{\mathrm{i}}$

$\mathrm{S}=\left\{\mathrm{S}_{1}, \mathrm{~S}_{2}, \ldots, \mathrm{S}_{\mathrm{k}}\right\}$

$k$ - number of clusters $(k \leq m)$

$m$ - number of observations (out of the area $R^{n}$ )

$\left(x^{(1)}, x^{(2)}, \ldots, x^{(m)}\right)-$ number of observations (Chy`gry`ns`ka \& Vlasyuk, 2006; Vojtovy`ch, 2010).

Sequence of the clustering by the k-means algorithm can be presented as follows:

Block I - initial - includes the following stages:

1) choice of initial points (centers) of clusters. This choice can be made either automatically on a random basis or by selecting the first k-observations;

2) assigning of each object of a set of observations to relevant clusters;

Block II - correcting - involves the redistribution of objects among clusters by the following stages:

1) calculating centroids of clusters; 
S. Shkarlet, N. Kholiavko, M. Dubyna. Information Economy: Management of Educational, Innovation, and Research Determinants

2) calculation of distances between each object of the analyzed total and centers of clusters (in any metric);

3) moving previous cluster centers to the centroid (the average of the coordinates of the objects assigned to the cluster);

4) iterations on the redistribution of objects between clusters to stabilize cluster centers - in accordance with the stop rule or the stop criterion of the algorithm also determine the minimum change in the root mean square error (2):

$$
\mu_{j}=\frac{1}{S_{j}} \sum_{x^{(j)} \epsilon S_{i}} x^{(j)}
$$

where, $\mathrm{x}$ - initial input data

$\mu_{i}, \ldots, \mu_{k}$ - centroids in clusters $\mathrm{S}_{1}, \mathrm{~S}_{2}, \ldots, \mathrm{S}_{\mathrm{k}}$

Note: the algorithm stops when centroid $\mu_{i}$ doesn't change, i.e., when $\mu_{i}{ }^{\mathrm{t}}=\mu_{i}^{\mathrm{t}+1}$ (Dubrov, Mxy taryan, \& Troshy`n, 1998);

Block III - testing - assessment of the quality of clustering, i.e. how clusters differ from each other:

1) calculation of mean values for each cluster;

2) quality assessment of the clustering.

Given the above, the k-means algorithm for our study can be visualized as follows - Figure 1.

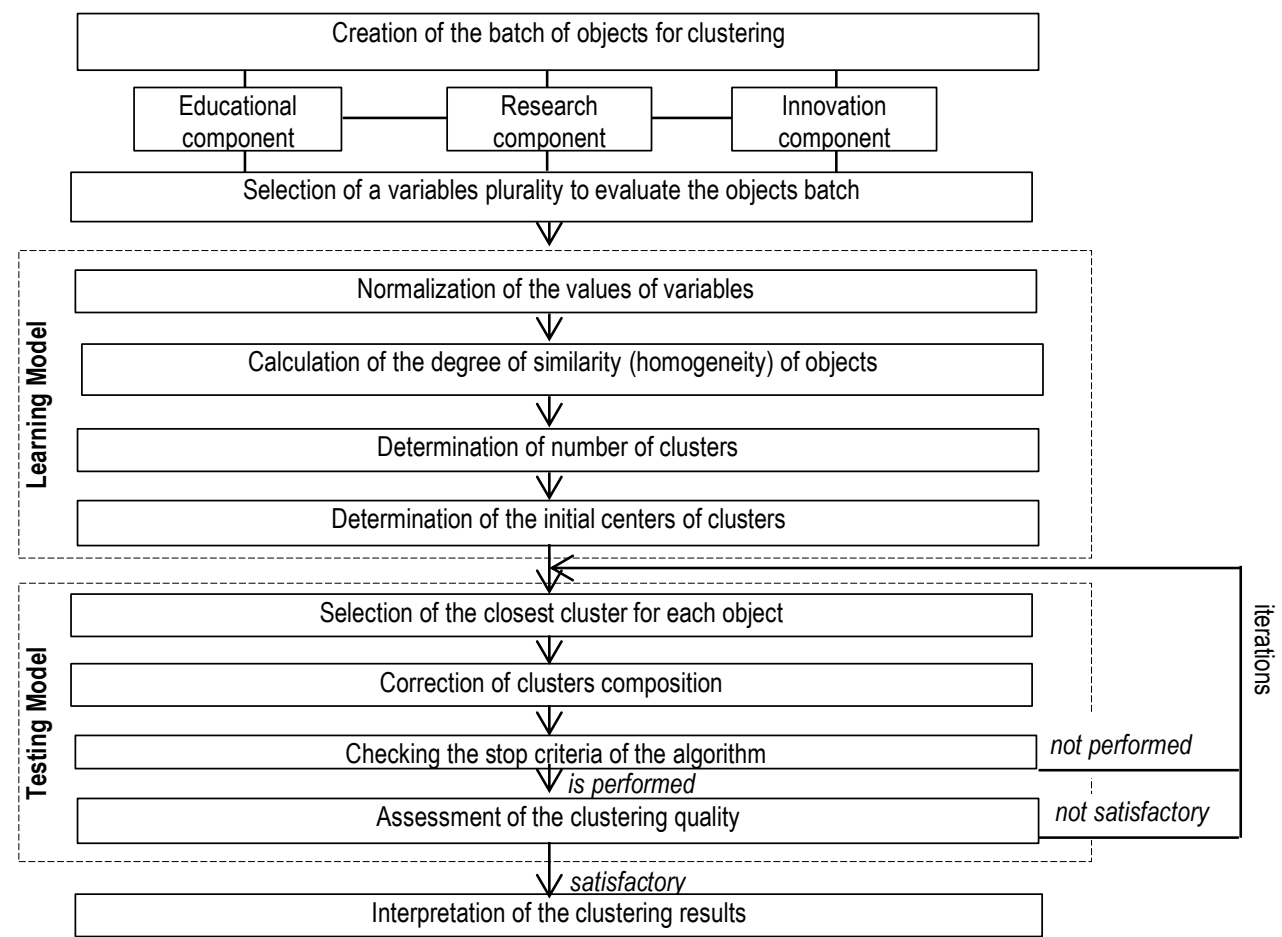

Figure 1. K-means algorithm for clustering the regions of Ukraine by the development level of Sources: compiled by the authors the information economy 
The choice of the proximity measure of objects, or metrics is very important by the cluster analysis. It is the metric distance between the objects of the analyzed observation that underlies the identification of similarity, which in turn determines their affiliation to certain clusters. The k-means algorithm works iteratively, which is usually accompanied by the migration of objects (in our case, regions) between clusters.

In course of the clustering process, objects under observation are represented as dots in multidimensional coordinate space. A characteristic vector (usually a set of numerical values) is formed for each object. In the next step, the selected indicators are normalized, i.e., they are reduced to a certain range (for example, [0; 1]). Only afterwards, the degree of similarity (distance) for each pair of objects is determined. The most common is the use of the function of the Euclidean distance (3):

$$
\rho(x, y)=\|x-y\|=\sqrt{\sum_{p=1}^{n}\left(x_{p}-y_{p}\right)^{2}},
$$

where, $\mathrm{p}(\mathrm{x}, \mathrm{y})$ - Euclidean distance,

$\mathrm{y}$ - input data of the objects, the distance between them is measured in n-dimensional space

$\mathrm{x}, \mathrm{y} \in \mathrm{R}^{\mathrm{n}}$ (Plyuta, 1980; Prokopenko \& Ganin, 2008).

In order to determine the strength of the correlation between partial indicators within each component of the information economy development, the Pearson's coefficient is calculated (4) (Plyuta, 1980; Turovs'ky'j, 2017):

$$
\mathrm{r}_{\mathrm{p}, \mathrm{xk}, \mathrm{yk}}=\frac{\sum\left(\mathrm{x}_{\mathrm{k}}-\mathrm{M}_{\mathrm{x}}\right)\left(\mathrm{y}_{\mathrm{k}}-\mathrm{M}_{\mathrm{y}}\right)}{\sqrt{\sum\left(\mathrm{x}_{\mathrm{k}}-\mathrm{M}_{\mathrm{x}}\right)^{2} \sum\left(\mathrm{y}_{\mathrm{k}}-\mathrm{M}_{\mathrm{y}}\right)^{2}}}
$$

where, $r_{p, x k, y k}$ - linear coefficient of the Pearson correlation;

$\mathrm{X}_{\mathrm{k}}, \mathrm{y}_{\mathrm{k}}$ - values of variables;

$M_{x}, M_{y}$ - assessment of the mathematical expectations of the values $x_{k}, y_{k}(5-6)$ :

$$
\begin{aligned}
& M_{x}=\frac{1}{n} \sum_{k=1}^{n} x_{k} \\
& M_{y}=\frac{1}{n} \sum_{k=1}^{n} y_{k}
\end{aligned}
$$

where, $\mathrm{x}, \mathrm{y}$ - input data of objects

$\mathrm{n}$ - batch volume (Soshny kova \& Tamashevy'ch, 1999).

Values of the coefficients of the Pearson correlation are within the range of the interval $[-1 ; 1]$. If $r_{p, x k, y k}$ moves to 1 , then the correlation between them is direct; if $r_{p, x k, y k}$ moves to -1 , then the correlation is inverse; if $r_{p, x k, y k}=0$, then there is no linear relationship between the indicators (however, this does not mean that there is no complete correlation between the indicators). The greater the absolute value of the Pearson coefficient is, the closer the linear correlation connection between the indicators is confirmed.

Results of the regional clustering in terms of components of the information economy development. In Figure 2, the correlation degree between the selected for clustering partial indicators is visualized: more intense coloration means smaller Pearson coefficient values, that is, a lower degree of correlation between indicators. Data in Fig. 2 testify to the statistical and mathematical validity of further processing.

Looking through Figure 2 in details, it should be noted that there is a close correlation between all partial indicators within each component. At the same time, the following indicators show a slightly lower 
S. Shkarlet, N. Kholiavko, M. Dubyna. Information Economy: Management of Educational, Innovation, and Research Determinants

degree of correlation: the amount of internal running costs for performing scientific-technical (experimental) elaborations is in the research component; the number of students of higher education institutions calculated pro 10 thousand of population - in the educational component; and partial indicators of the innovation component (in comparison with other two components of the information economy development) are characterized by much higher level of independence.

a) research component

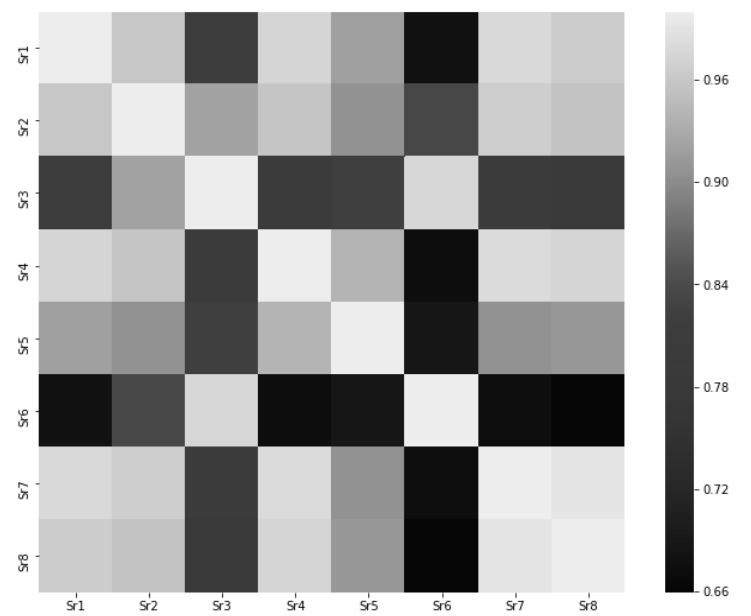

b ) innovation component

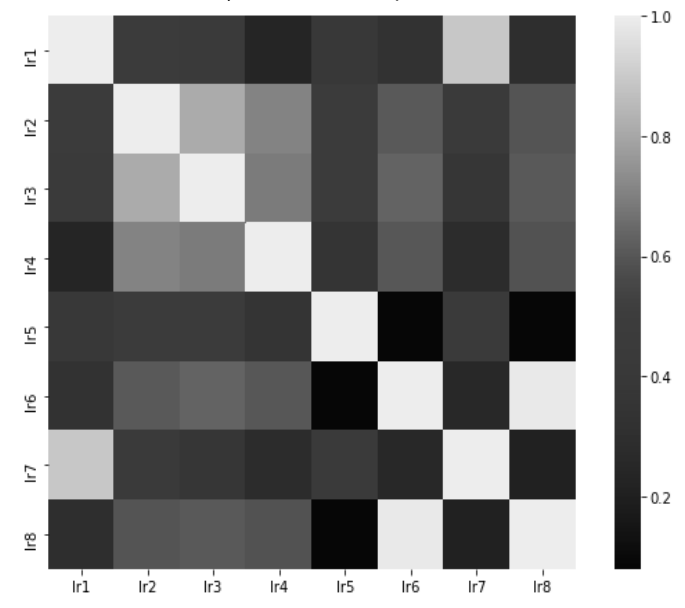

c) educational component

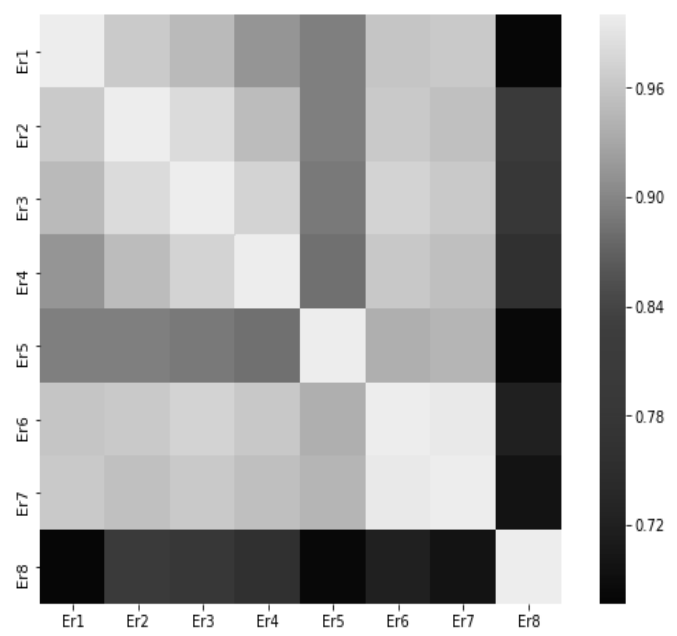

Figure 2. Charts of the indicators correlation: a) research; $b$ ) innovation; c) educational components of the information economy development on the regional level

Sources: compiled by the authors

Performed calculations, iterative metrics made it possible to cluster the regions of Ukraine according to educational, research and innovation components of the information economy development. Results of the cluster analysis allow us to formulate the following conclusions. In course of clustering the regions 
S. Shkarlet, N. Kholiavko, M. Dubyna. Information Economy: Management of Educational, Innovation, and Research Determinants

of Ukraine by the research component of the information economy, three groups are outlined (Figure 3). Kharkiv region was recognized as a leader; Dnipro and Lviv regions are assigned to perspective regions with the average development level. Other regions of Ukraine (21 regions) are included in the cluster, which objects are characterized by the low development level of the set of parameters of the research component.

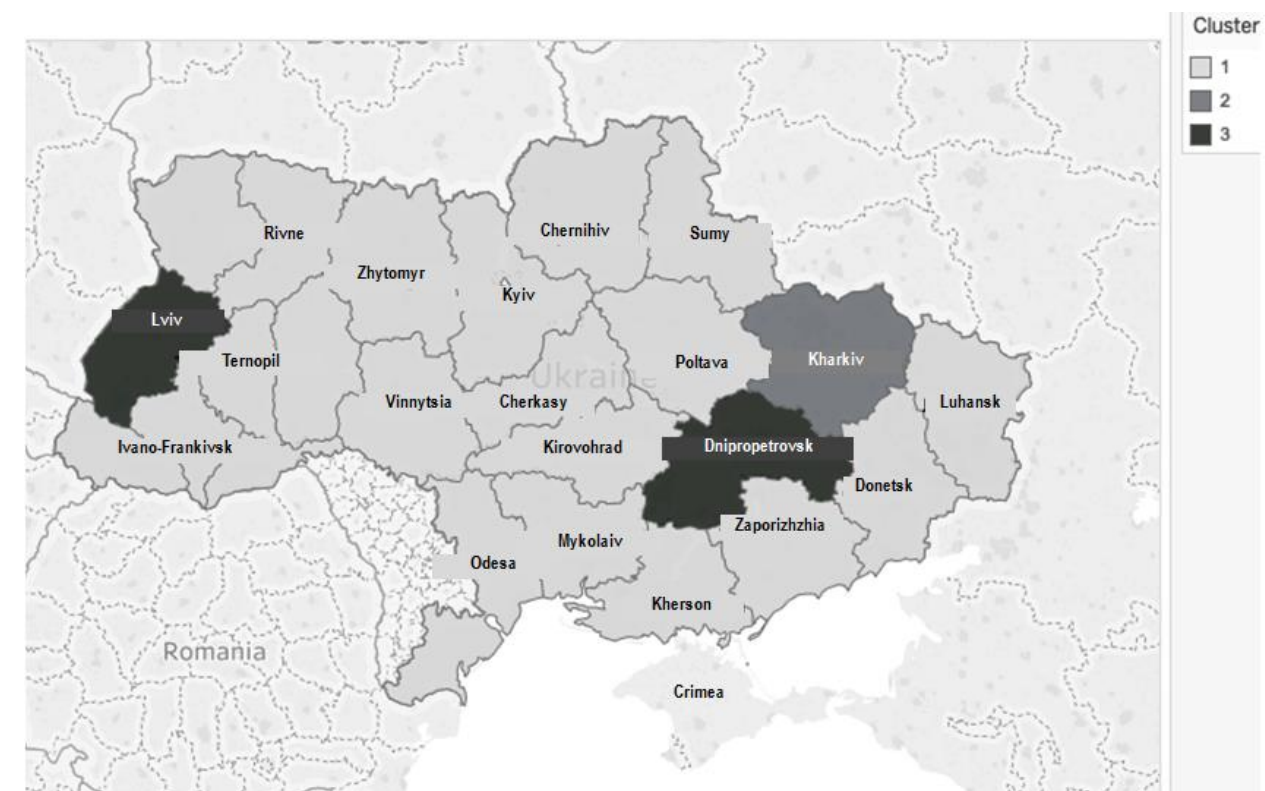

Figure 3. Cluster distribution of the regions: the research component of the information

Sources: compiled by the authors economy development

The largest cluster ( $88 \%$ of the analyzed regions) is the first cluster. It contains regions that demonstrate heterogeneous tendencies of the development of the research component of the information economy. Despite existing opportunities and reserves (availability of scientific-research institutes and higher education institutions, that, in addition to teaching conduct research activity), regions included in the first cluster at the current stage are not able to ensure successful implementation of the available potential. The reasons for this, in our opinion, are the declarative nature of the priority of scientific and technological development; low level of the commercial attractiveness, applied value of $R \& D$ results; insufficient motivation of the research and educational staff to improve the quality of research; predominantly fundamental, theoretically oriented research, low practical value and commercial attractiveness of their results.

The second cluster includes Kharkiv region, which demonstrates the intensive development by the research component of the information economy. Leadership positions in this field are substantiated by the efficient functioning of organizations carrying out research and development (about 150), and scientists in particular (about 10 thousand). There are powerful universities in Kharkiv region (Kharkiv Polytechnic Institute, Kharkiv National University named after V.N.Karazin, Kharkiv National Medical University, etc.), that concentrate the intellectual potential and conduct thorough research. It is in this region of Ukraine that one of the highest indicators of funding for research is observed in Ukraine, including basic, applied research, scientific and technical (experimental) development. 
S. Shkarlet, N. Kholiavko, M. Dubyna. Information Economy: Management of Educational, Innovation, and Research Determinants

The third cluster is presented by two regions that demonstrate the average development level of the research component. In our opinion, subject to the synchronization of interests and coordination of activities of subjects of state, business, educational and public sectors (The Quadruple Helix Carayannis \& Grigoroudis Model, 2016), intensification of the scientific and technological development of Lviv and Dnipropetrovsk regions is possible. Moreover, Dnipropetrovsk region has more perspectives to move from the third cluster to the second one, in view of the dynamics of statistical indicators (for example, the number of scientists, the amount of internal current costs for applied research and experimental development). In turn, establishing such correlation will create stable preconditions for activating the development of the information economy by increasing the effectiveness of research and their commercialization in the real sector of the national economy.

The research component of the information economy influences the dynamics of the innovation component. This is reflected in results of the clustering of the regions of Ukraine by the innovation component - Figure 4. Effective implementation of the existing potential and attraction of talents to the region have provided the leading positions in Kharkiv region by the innovative component (cluster 2). The cluster of perspective regions with the average development level (cluster 3), besides Dnipro and Lviv regions, has been completed with Zaporizhzhia and Odesa regions. Moreover, the leadership in this cluster is taken by Zaporizhzhia region, the second place is Dnipro region. Majority of the regions of the country (79\%) were related to cluster 1 , which objects are characterized by the low development level of partial indicators of the innovation component of the information economy.

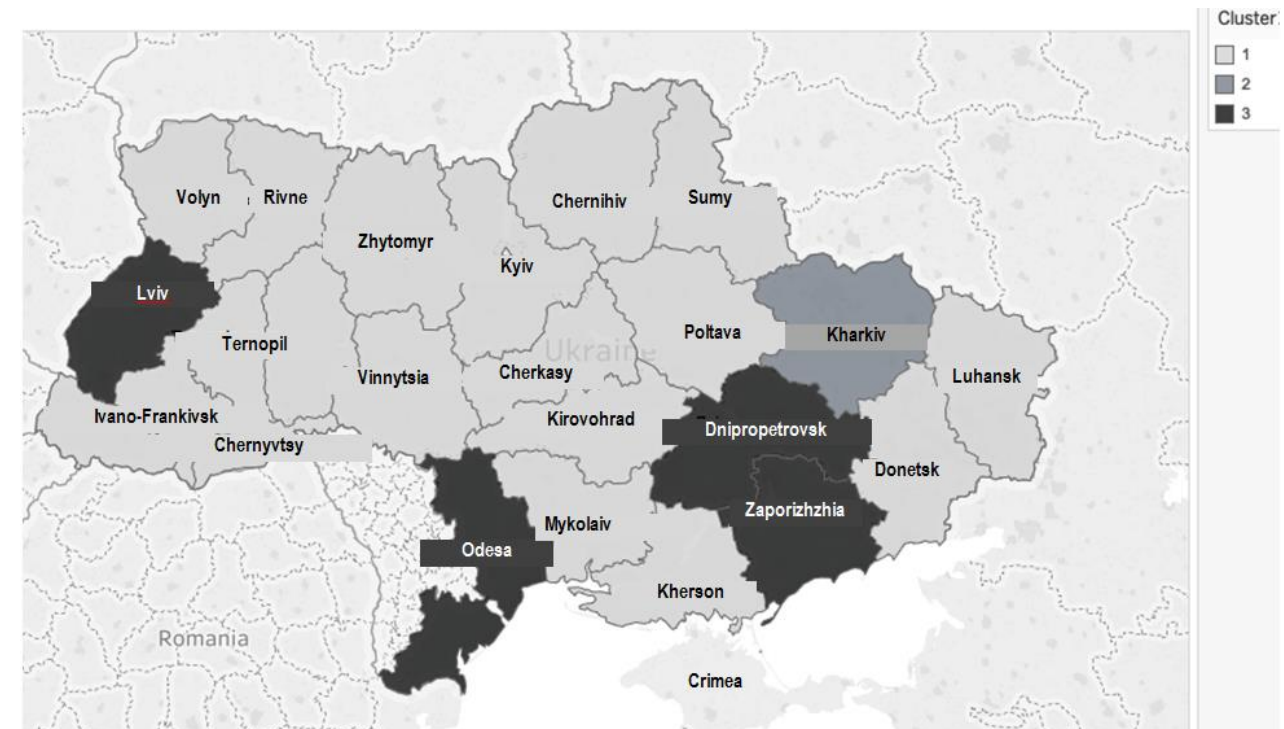

Figure 4. Cluster distribution of the regions: the innovation component of the information economy development

Sources: compiled by the authors

It should be noted that this component of the information economy development in Ukraine is the most problematic for all regions of the state. Disruption of the correlation between subjects of the Quadruple Helix model leads to the fact that:

- state and local authorities make unsubstantiated decisions on investing innovative activities (in terms of spheres and industries); 
- higher education institutions generate innovative ideas, often devoid of commercial value, with low levels of the investment attractiveness;

- enterprises spend financial resources on innovative projects, the implementation of which ultimately does not bring the projected level of profitability due to their lack of validity (technical, economic, scientific);

- innovation culture in the society is underdeveloped, employees have not developed innovative thinking and skills of using modern information and communication technologies in professional activity.

The educational component of the information economy is considered a structuring by us (Figure 5). This view can be explained by the fact that it is in the higher education system of the country that the overwhelming majority of scientists, teachers of the country are employed. The educational component partially integrates in its structure the elements of research and innovation components of the information economy. The analysis of the research and innovation components revealed the increasing contribution of higher education institutions to the development of the information economy. In particular in the following directions: a) training of the scientific staff, as well as future specialist able to think and act innovatively; formation of a new generation of entrepreneurs capable of doing business in the context of the informatization, digitalization of the world economy; b) generation of innovative ideas, development of new technologies and modernization of technology during the implementation of research activities. In other words, the higher education system, on the one hand, provides staffing for the development of the information economy, and on the other hand, the direct research and validation of their results.

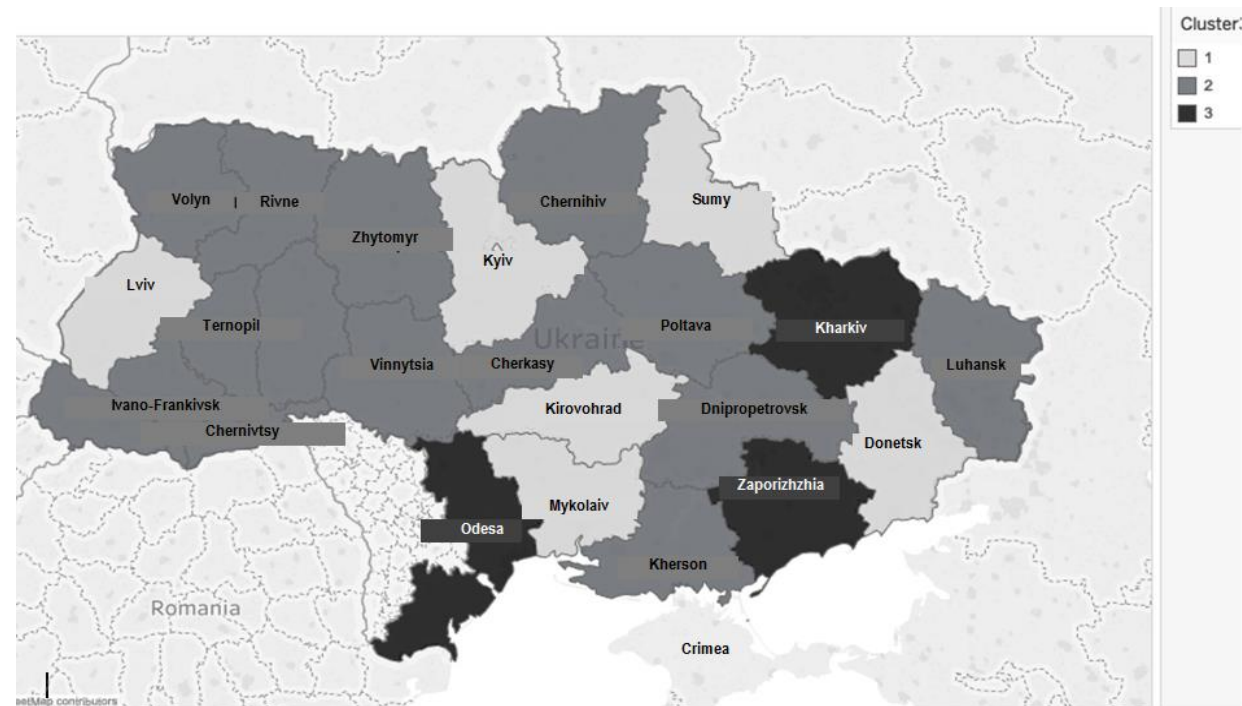

Figure 5. Cluster distribution of the regions: the educational component of the information

Sources: compiled by the authors

Therefore, according to the cluster analysis, the group of regions with the intensive development (cluster 3) includes Odesa, Zaporizhzhia and Kharkiv regions; the cluster of perspective regions with the average development level (cluster 1) includes Kyiv, Kirovograd, Donetsk, Lviv, Mykolaiv and Sumy regions; the rest - are assigned to the cluster of regions with the low development level of the 
S. Shkarlet, N. Kholiavko, M. Dubyna. Information Economy: Management of Educational, Innovation, and Research Determinants

educational component (15 regions which makes $62 \%$ of analyzed regions) - Fig. 5. Obtained results showed that the educational component has the biggest perspectives by the intensification of the information economy development. Moreover, we are talking about complex engagement of the potential of higher education institutions, including the state support and stimulation of the development of not only educational but also research and innovation activity of universities.

Modern optimization processes in the higher education system of the country are accompanied by a decrease in the number of educational institutions. These processes are aimed at consolidating universities, transforming them into regional centers of the talent attraction, economic entities capable of attracting and making effective use of investment resources. In practice, implementation of the aforementioned faces difficulties that require full consideration of specific needs of individual regions of Ukraine. This applies both to the professional and qualification structure of professionals in demand in local labor markets, as well as to the structure, profile orientation and quality performance of the university research. Inconsistency of the state policy on optimization in the higher education system with meso-economic challenges causes a deepening imbalance in the processes of the establishing the information economy at the regional level, breach of the correlation between the higher education, business, government and society.

The next stage of our study was a consolidated clustering of the regions of Ukraine for the totality of selected indicators (Table 2). In order to minimize the error and detail the results obtained by the integrated clustering, a bigger number of clusters were isolated $(k=4)$ - Table 3.

Table 3. Results of the consolidated clustering of the regions by the development level of the information economy

\begin{tabular}{|c|l|l|}
\hline Cluster & \multicolumn{1}{|c|}{ Regions } & \multicolumn{1}{c|}{ Cluster description } \\
\hline 1 & $\begin{array}{l}54 \% \text { of the analyzed regions: } \\
\text { Volyn, Donetsk, Zhytomyr, } \\
\text { Transcarpathia, Kyiv, Kirovohrad, } \\
\text { Luhansk, Mykolaiv, Rivne, Kherson, } \\
\text { Khmelnytskyi, Chernivtsi, Chernihiv }\end{array}$ & $\begin{array}{l}\text { regions with the low level of the information economy } \\
\text { development: problematic regions, in which randomness and } \\
\text { selectivity are observed in the processes of establishing the } \\
\text { information economy; regions-outsiders that are just in the } \\
\text { early stages of the information economy }\end{array}$ \\
\hline 2 & $\begin{array}{l}13 \% \text { of the analyzed regions: } \\
\text { Dnipropetrovsk, Lviv, Odesa }\end{array}$ & $\begin{array}{l}\text { regions with the dynamic development of the information } \\
\text { economy: regions that have reserves to increase the pace of } \\
\text { informatization of the economy and in the future - to move } \\
\text { into a cluster of regions with the intensive development }\end{array}$ \\
\hline 3 & $\begin{array}{l}4 \% \text { of the analyzed regions: } \\
\text { Kharkiv }\end{array}$ & $\begin{array}{l}\text { a region with the intensive development of the information } \\
\text { economy. Both integral clustering and clustering in terms of the } \\
\text { components have confirmed leader positions of Kharkiv region }\end{array}$ \\
\hline 4 & $\begin{array}{l}29 \% \text { of the analyzed regions: } \\
\text { Vinnytsia, Zaporizhzhia, } \\
\text { Frankivsk, Poltava, Ternopil, Cherkasy- }\end{array}$ & $\begin{array}{l}\text { perspective regions with the average development level of the } \\
\text { information economy: regions characterized by the uneven } \\
\text { dynamics of the information economy development; they have } \\
\text { necessary potential (intellectual, scientific-technical, innovation) } \\
\text { in order to activate processes of the information economy } \\
\text { informtization }\end{array}$ \\
\hline
\end{tabular}

Sources: compiled by the authors

Let us analyze the obtained results of clustering. Regions included in the first cluster are problematic regions with the low level of the information economy development. This is due to the low level of their economic, social development, low entrepreneurial activity; lack of effective motives for the implementation of research activities; obsolescence of the material and technical base of scientific institutions and universities, which limits the possibility of thorough research. Inert development and low innovation activity of local businesses, disruption of business contacts between higher education 
institutions and enterprises, ineffective state policy on supporting science and education lead to the emergence of destructive phenomena in the processes of the economy informatization. Such regions need state support to increase the investment attractiveness of the science, higher education, diversified sources.

The second cluster unites regions, that have similar economic development trends, are characterized by favorable economic and geographical location, have significant potential, have developed financial and credit systems, and are able to attract highly qualified personnel. These areas are characterized by the investment attractiveness of the higher education, science and innovation. Research activity of universities of Odesa, Lviv, Dnipropetrovsk regions is focused on the applied and experimental development and focused on generating commercially attractive results in response to actual challenges of the business sector.

Leading positions of Kharkiv region are obvious, which is substantiated by its dominance over a number of analyzed indicators:

- the number of scientists, postgraduates, doctoral students, students (including in calculations per 10 thousand of population testifies to the powerful human and intellectual potential);

- the volume of introduced new technological processes, innovative products, number of applications and patents for inventions indicates the high efficiency of the research and innovation activity of subjects in comparison with other regions of the country;

- costs volume on research and innovation demonstrates awareness of the importance of science and innovation in the economic development at micro- (enterprises), meso- (regions) and macro-levels (national economy), manifested in the growth of the investment in scientific and innovative projects, creates opportunities for the development of the innovative and information infrastructure, allows to update the material and technical base of research and educational institutions.

Conclusions. To sum up, we can state that processes of establishing the information economy in Ukraine are developing unevenly. Such unevenness at the level of different regions of the country can activate processes of establishing the information economy, however, provided that found disparities are objectively conditioned, regulated, moderate. In our opinion, activation of the processes of the formation of the information economy in Ukraine requires improvement of approaches to state regulation, which cannot be universal, but must be based on specific features of the regions, their smart specialization, actual capacities and the achieved level of the development of the information economy components. Strategic guidelines for the state support for regions with the intensive and dynamic development of the information economy should be defined as follows: stimulation of the development of the innovative, research, educational activity; contributing to maintaining growing trends of the information economy development; accelerating the commercialization pace of the R\&D results in higher education institutions; guaranteeing respect for intellectual property rights; deepening the interaction of the subjects of the Quadruple Helix model; widespread support for innovative actors; enhancing the investment attractiveness of the education and science.

Vectors of the strategic development of perspective regions with the average pace of the information economy establishing should be aimed at creation of favorable conditions for further structural changes. It is important to identify systematically (at national and regional levels) factors that stimulate the development of educational, research and innovation components of the information economy. For this group of regions of Ukraine, it is extremely important to attract investment for the development of the information and innovation infrastructure.

The calculations showed that the information economy in Ukraine is only at the stage of formation; the largest number of regions of the state falls into the cluster of problematic regions with low development levels of educational, innovation and research components. Such regional distribution reflects the difficult social and economic situation in Ukraine, which is difficult to forecast in the medium 
and long term. The group of problematic regions needs the utmost attention from the public sector. In our opinion, particular emphasis should be placed on the intensification of the higher education and science, namely:

- enhancing the competitiveness of universities by increasing the quality of educational services;

- harmonization of the higher education institutions with the demands of the business sector, bringing it in line with the smart specialization of regions;

- investing in updating the material and technical base of educational and research institutions;

- increasing the pace of implementation of the latest information and communication technologies;

- skills development by future staff to work with modern information and communication technologies, development of the information literacy of the population, etc.

The problem of financing the educational, research and innovation activity is common to all regions of Ukraine.This is caused, first, by low investment attractiveness of educational and science fields; second, by low diversification of funding sources for educational and scientific institutions; third, by nonsynchronization of the subjects of the Quadruple Helix Model; fourth, by insufficient level of the innovation activity of domestic business. Thus, the need to develop and implement a comprehensive strategy for state regulation of the processes of the formation and development of the information economy becomes justified. Moreover, the development of such a strategy should be based on the synergistic approach, taking full advantage of the partnerships of the entities of the Quadruple Helix Model.

Acknowledgments. This research is carried out within the framework of the research project «Integrated Model of Competitive Higher Education in Ukraine under the Quadruple Helix Concept» (№ 0117U007258) with the support of the Ministry of Education and Science of Ukraine.

Author Contributions: conceptualization and supervision, S. M. Shkarlet; methodology, M. V. Dubyna and N. I. Kholiavko; investigation and writing, S. M. Shkarlet, N. I. Kholiavko and M. V. Dubyna; formal analysis and visualization, N. I. Kholiavko; review and editing, S. M. Shkarlet.

\section{References}

Arthur, D., Vassilvitskii, S. (2006) How slow is the k-means method? In SCG '06: Proceedings of the twenty-second annual symposium on computational geometry. ACM Press.

Artuhur, D., Vassilvitskii, S. (2007) K-means++: The Advantages of Careful Seeding. Proceedings of the Eighteenth Annual ACM-SIAM Symposium on Discrete Algorithms. pp. 1027-1035.

Bell, D. (1973) The Coming of Post-industrial Society: A Venture of Social Forecasting. New York : Basic Books. 507 p.

Bezvushko, Ye. (1999) Klastery' ta yix rol' u vidrodzhenni ekonomiky' Podillya [Clusters and their role in the revival of the economy of Podillya] Perspective studies. №2. P. 17-23.

Bottou, L. \& Bengio, Y. (1995) Convergence properties of the k-means algorithm. Advances in Neural Information Processing Systems.

Butenko, A. I., Lazaryeva, Ye. V. (2009) Fenomen klastera u formuvanni innovacijnoyi modeli ekonomiky` regionu [The phenomenon of the cluster in the formation of an innovative model of the region's economy] Investments: practice and experience. No. 2. C. 25-28. URL: http://www.investplan.com.ua.

Carayannis, E. \& Grigoroudis, E. (2016) Quadruple Innovation Helix and Smart Specialization: Knowledge Production and National Competitiveness. Foresight and STI Governance. vol. 10. № 1. Pp. 31-42.

Castells, M. (1997) The Information Age: Economy, Society and Culture: The Power of Identity. Oxford : Blackwell, 1997. $461 \mathrm{p}$

Chy'gry'ns'ka, O.S., Vlasyuk, T.M. (2006) Teoriya ekonomichnogo analizu [The theory of economic analysis] K.: Center for Educational Literature.232 $\mathrm{p}$.

Dubrov, A.M., Mxy`taryan, V.S., Troshy'n, L.Y'. (1998) Mnogomernble staty 'sty'chesky'e metody [Multidimensional statistical methods] M.: Fy'nansy y' staty'sty'ka. $350 \mathrm{p}$.

Elkan, C. (2003) Using the triangle inequality to accelerate k-means. Proceedings of the Twentieth International Conference on Machine Learning, Volume 3, pp. 147-153. 
S. Shkarlet, N. Kholiavko, M. Dubyna. Information Economy: Management of Educational, Innovation, and Research Determinants

Har-Peled, S., Sadri, B. (2005) How fast is the k-means method? In SODA'05: Proceedings of the sixteenth annual ACMSIAM symposium on Discrete algorithms, pages 877-885, Philadelphia, PA, USA, 2005. Society for Industrial and Applied Mathematics.

Hartigan, J.A. and Wong, M.A. (1979) A k-means clustering algorithm. Applied Statistics, Vol. 28, pp. 100-108.

Ivanov, Yu., Tyshchenko, V. (2015) Public-private partnership potential in knowledge economy: regional aspect. Economic Annals-XXI. № 3-4(1). Pp. 28-31. URL: http://nbuv.gov.ua/UJRN/ecchado_2015_3-4\%281\%29_8

Jain, A. J., Murty, M.N., Flynn, P.J. (1999) Data clustering: a review. ACM Computing Surveys. V. 31. № 3. Pp. 264-323.

Kanungo, T., Mount, D.M., Netanyahu, N.S., Piatko, C.D., Silverman, R., Wu A.Y. (2004) A local search approximation algorithm for k-means clustering. Comput. Geom., 28(2-3):89-112.

Korepanov, O.S. (2018) Adaptaciya metody 'chnogo zabezpechennya do specy' fiky' ocinyuvannya tery 'torial'nogo rozvy'tku informacijnogo suspil'stva v Ukrayini [Adaptation of methodological support to the specifics of the evaluation of the territorial development of the information society in Ukraine] Business Inform. №4. P. 364-370.

Ky'm, Dzh.-O. (1989) Faktornyj, dy 'skry'my'nantnyj y' klasternyj analy'z. [Factorial, discriminant and cluster analysis.] M. : Finances and statistics. $215 \mathrm{p}$.

Masuda, Y. (1983) The Information Society as Postindustrial Society. Washington: Word Future Soc. P. 45.

Mielikainen, J. (2002). A novel full-search vector quantization algorithm based on the law of cosines. IEEE Signal Processing Letters. No 9. Pp. 175-176.

Mikula, N. (2003) Yevroregiony': dosvid ta perspekty'vy' [Euroregions: experience and perspectives] Lviv: IRD NAS of Ukraine. $222 p$

Pankaj, K. (2004) Agarwal and Nabil H. Mustafa. K-means projective clustering. PODS '04: Proceedings of the twenty-third ACM SIGMOD-SIGACT-SIGART symposium on Principles of database systems. Pp. 155-165, New York, NY, USA. ACM Press.

Plyuta, V. (1980) Sravny'tel'nyj mnogomernyj analy'z v ekonomy'chesky'x y'ssledovany'yax. Comparative multidimensional analysis in economic research. M.: Statistics $143 \mathrm{p}$.

Porat, Mark U. (1977) The Information Economy. Nine volumes. Office of Telecommunication, US Department of Commerce. Washington.

Prokopenko, I.F., Ganin, V.I. (2008) Metody'ka i metodologiya ekonomichnogo analizu Methodology and methodology of economic analysis. K.: Center for Educational Literature. $430 \mathrm{p}$.

Sculley, D. (2010) Web Scale K-Means Clustering. Proceedings of the 19th International Conference on World Wide Web. pp. 1177-1178.

Sokolenko, S. (2004) Klastery' $v$ global'nij ekonomici [Clusters in the global economy] K.: Logos.

Soshny'kova, L.A., Tamashevy'ch, V.N. (1999) Mnogomernyj staty'sty'chesky”j analy'z v ekonomy’ke [Multivariate statistical analysis in the economy] M. : YuNY'TY'. $598 \mathrm{p}$

Toffler, A.(1980) The Third Wave. New York : Bantam Books. 544 p.

Turovs'ky'j, I. V. (2017) Ekonometry'chny’j pidxid do klastery'zaciyi regioniv Ukrayiny' za rivnem social'no-ekonomichnogo rozvy'tku [Econometric approach to clusterization of regions of Ukraine by the level of socio-economic development] Scientific herald of Uzhgorod National University: Series: International Economic Relations and World Economy / Heads. edit MM Palinchak Uzhhorod: Helvetia. Vol. 14. Part.2. P. 147-152.

Vojnarenko, M. P. (2011) Klastery' v insty 'tucijnij ekonomici: monografiya [Clusters in the institutional economy: a monograph] Xmel'ny”cz'ky”j: XNU, TOV «Triada-M». 502 p.

Vojtovy'ch, A.D. (2010) Klastery'zaciya regioniv za rivnem social'no-ekonomichnogo rozvy'tku [Clusterization of regions on the level of socio-economic development] Bulletin of the Khmelnytsky National University. №4. Vol. 1.P. 248-252.

Wu, X., Kumar, V. (2009) The Top Ten Algorithms in Data Mining. Chapman \& Hall. CRC.

С. М. Шкарлет, д.е.н., профресор, Чернігівський національний технологічний університет (Україна);

Н. І. Холявко, к.е.н., доцент, Чернігівський національний технологічний університет (Україна);

М. В. Дубина, д.е.н., доцент, Чернігівський національний технологічний університет (Україна).

Інформаційна економіка: менеджмент інноваційної, освітньої та дослідницької детермінант

Глобальним трендом економічного розвитку є перехід до формування нового економічного укладу - інфоормаційної економіки. Здатність до генерації знань та інновацій стає передумовою підвищення конкурентоспроможності країни та іï регіонів, а також визначає темпи їх соціально-економічного розвитку. У такому контексті актуалізується необхідність визначення рівнів розвитку інфоормаційної економіки та ії структурних компонент (освітньої, дослідницької, інноваційної) у регіонах країни. Метою статті є розробка й апробація методичного інструментарію оцінки розвитку інформаційної економіки у розрізі їі структурних компонент, що дозволить ссрормувати регіональні кластери за інтенсивністю освітньої, інноваційної й дослідницької компонент, а також визначити пріоритетні вектори стимулювання розвитку інфрормаційної економіки на макро- та мезоекономічному рівнях. При розробиі методичного інструментарію автори виходили з існуючих у світі методичних підходів, можливості їх адаптації до національної специфріки, а також потенціалу статистичних баз. Для здійснення кластеризації регіонів України за 
S. Shkarlet, N. Kholiavko, M. Dubyna. Information Economy: Management of Educational, Innovation, and Research Determinants

рівнем розвитку освітньої, інноваційної та дослідницької компонент інформаційної економіки використано алгоритм kmeans. Проведений кластерний аналіз показав, що процеси становлення інфоормаційної економіки в Україні розвиваються нерівномірно та перебувають на етапі становлення. Більша кількість областей держави потрапляє в кластер проблемних регіонів з низьким рівнем розвитку освітньої, інноваційної та дослідницької компонент; лідерські позиції за рівнем розвитку інфрормаційної економіки демонструє Харківська область, віднесена до кластеру регіонів з інтенсивним розвитком інформаційної економіки; виокремлено також кластер перспективних регіонів із середнім рівнем розвитку інформаційної економіки. Проведене дослідження дозволило виявити основні проблемні моменти та ідентифікувати зони виникнення регіональних дисбалансів в розвитку інформаційної економіки, у тому числі в розрізі їі структурних компонент. У висновках авторами запропоновано напрями вдосконалення підходів до державного регулювання процесів становлення інформаційної економіки, що грунтуються на врахуванні специфрічних особливостях регіонів, їх смарт-спеціалізації, фрактичних потужностей та досягнутого рівня розвитку компонент інформаційної економіки.

Ключові слова: інформаційна економіка, регіон, інновації, вища освіта, R\&D, кластер, освітня компонента, інноваційна компонента, дослідницька компонента.

Manuscript received: 19.06.2019.

(C) The author(s) 2019. This article is published with open access at Sumy State University. 